\title{
ORGANIZATION OF ACTIVITIES OF PATROL POLICE, SECURITY POLICE AND SPECIAL PURPOSE POLICE
}

\section{Rachinska I. M.}

\section{INTRODUCTION}

This work highlights the main issues relating to the organization and activities of the newly established Institute-patrol police, namely: legal regulation and principles of the patrol police of Ukraine; tasks and functions of the patrol police; organization of the patrol police of Ukraine; rights and duties of the inspector of the patrol police of Ukraine; administrative and jurisdictional activities of the inspector of the patrol police of Ukraine regarding the consideration of cases of administrative offenses. As well as other issues associated with: the legal regulation of police activities for the protection; the main tasks and functions of the special purpose police; the rights and duties of the special purpose police.

\section{Legal regulation and principles of the patrol police of Ukraine}

Since the adoption of the Act of proclamation of independence of Ukraine, political, economic and social changes have taken place, along with a significant democratization of public relations. A big step in the development of the independent state was the signing of the agreement between Ukraine and the European Union on associate membership on June 27, 2014. One of the important factors of Ukraine's entry into the Commonwealth of European States should be the implementation of a large number of reforms in many spheres of public and political life. One of these reforms was the reform of law enforcement agencies of Ukraine.

The system of internal Affairs of Ukraine was largely built on the achievements of the Soviet Union. In 1990, the law of the Ukrainian SSR "on police" laid the legal basis for the functioning of the modern police of Ukraine. This law until recently was the fundamental document of its activity. However, some questions of activity of militia were settled by other legislative acts. In particular, the issue of the structure of internal Affairs bodies and the number of their employees is regulated by the Law of Ukraine "on the General structure and number of the Ministry of internal Affairs of Ukraine", and the issue of disciplinary proceedings and the Law "on the Disciplinary Statute of internal Affairs bodies of Ukraine". During the independence of Ukraine, large-scale reform did not happen. With each change of state power, there were attempts to modernize the system of internal 
Affairs bodies (only 9 attempts), however, as a rule, the reform process did not give the large-scale, global results that were needed.

In recent years, more and more has been said about the inefficiency of the Ukrainian system of internal Affairs, which is explained by its inconsistency with modern democratic social, economic and political realities. The need to reform the internal Affairs bodies is confirmed by the results of an expert survey conducted by the International center for advanced studies in the period from July to September 2015. Thus, $65 \%$ of respondents recognized the reform of law enforcement agencies as the most important task of the government.

Thus, the European way of development of Ukraine requires a reassessment of the activities of all components of the public authorities, the direction of their functioning to ensure the rights and freedoms of the citizen. A special place is given to the reform of the law enforcement sector, in particular the Ministry of internal Affairs ${ }^{1}$.

All this became prerequisites of creation by the Expert Council of the Ministry of internal Affairs of the Main actions for reforming of law enforcement Agency. On October 22, 2014, the Cabinet of Ministers of Ukraine approved the Concept of reforming the Ministry of internal Affairs and the Strategy for the development of internal Affairs bodies. It became a certain start for the beginning of carrying out strategic reform of militia. Which should result in a new European law enforcement Agency whose mission is to serve and protect.

AcOSACing to the development Strategy of Ukraine 2020, the goal of the state policy in the field of reforming the law enforcement system was to adjust the tasks and functions of law enforcement agencies, the introduction of new principles of service, new criteria for assessing the work of law enforcement officers to improve the protection of human rights and freedoms, as well as the interests of society and the state from illegal encroachments. The new system of the Ministry of internal Affairs is a civil body that forms the state policy in the areas of combating crime and ensuring public security and order (public order), integrated management of the state border, combating illegal migration, civil protection, fire safety and combating emergency situations by creating specialized departments.

Thus, the objectives of the reform of the MIA are:

- demilitarization of the Ministry of internal Affairs;

- reduction of a significant number of bodies, units and services with related tasks and functions;

\footnotetext{
${ }^{1}$ Violence in the family and the police to overcome it: training manual for cadets of higher educational institutions of the Ministry of internal Affairs of Ukraine / compilers: Zaporozhtsev A., Laban A., Zabroda D., Bassist I., Drozdova I., Brizhik V. Kiev, 2012. 246 p.
} 
- ensuring effective coordination of activities and coordinated interaction of the National police, National guard, border, migration services, as well as emergency services under the political leadership of the Ministry of internal Affairs;

- legislative definition of the updated General structure of the Ministry of internal Affairs, structure and number, tasks and powers of internal Affairs bodies and other conditions of their activity, the priorities of which is the implementation of social and service functions;

- depoliticization of the activities of bodies and services controlled by the Ministry of internal Affairs, their autonomy and optimization;

- elimination of duplication of functions of offices, departmental enterprises, institutions and organizations;

- introduction of the European model of training and advanced training of personnel of internal Affairs bodies, application of uniform unified standards of law enforcement training aimed at improving the efficiency of interaction between the internal Affairs bodies of different member States of the European Union;

- development of effective means and mechanisms of control over the activities of internal Affairs bodies and individual police officer;

- increasing public confidence in the activities of the internal Affairs bodies, as well as the authority of the employee of the internal Affairs body;

- increasing the role of civil society institutions and local selfgovernment bodies in measures to ensure the rights and freedoms of the population;

- establishing close cooperation with the population and local communities.

To achieve the above objectives, the following tasks must be performed:

- complete the certification of personnel;

- change of heads of both Central and regional departments of the Ministry of internal Affairs;

- reduction of the administrative apparatus (city administrations);

- reorganization of the special forces unit;

- creation and deployment of the patrol police as a full-fledged structure of public order;

- formation of a unit to combat crimes in cyberspace acOSACing to new principles;

- reorganization of the unit for combating economic crimes;

- liquidation of the unit for combating drug trafficking;

- creation of the expert service independent of regional and district chiefs of the Ministry, that is completely with direct submission to the Minister;

- reforming the National Guard, which will be staffed on the basis of professional requirements exclusively from volunteers; 
- volunteer battalions of the Ministry of internal Affairs will eventually be disbanded, and their members will move to the professional structures of the police and the national guard.

Another point is the formation of the National police as it is the Central Executive body that serves society by ensuring the protection of human rights and freedoms, combating crime, maintaining public security and order, with the following structure: criminal police; patrol police; pre-trial investigation bodies; security police; special police.

The reform of the system of internal Affairs bodies also provides for the adoption of four basic laws: "On internal Affairs bodies", "on the National police", "on services and service centers of the Ministry of internal Affairs of Ukraine", "on amendments to some legislative acts of Ukraine on improving the regulation of relations in the field of road safety" 2 .

The first stage of the reform was the creation of a patrol police. The creation of a patrol police differs from other government initiatives in several points. First, a new institution was created, the selection of personnel in which was transparent, but which should continue throughout the first phase of the reform. As the Georgian experience shows, for the selection of several thousand qualified and uncorrupted employees, several waves of "screening" are needed, since final conclusions about the professional suitability of some personnel can be made only on the basis of their actions in real conditions, and not only during testing and training.

Second, in addition to new institutions, reform requires new procedures, standards and skills. During the training, the emphasis was not on theory, but on the study of about 500 procedures-scenarios in which the new patrol should operate. Thirdly, the key to a new quality of the police should be a high level of salaries and strict internal control mechanisms.

Patrol police in its activity is guided by Constitution of Ukraine, international treaties of Ukraine agreed to be binding by the Verkhovna Rada of Ukraine, laws of Ukraine" On the national police"; "On amendments to some legislative acts of Ukraine on improving regulation of relations in the sphere of ensuring road traffic safety", "On Disciplinary Statute of bodies of internal Affairs of Ukraine"), acts of the President of Ukraine and resolutions of Verkhovna Rada of Ukraine, accepted acOSACing to the Constitution and laws of Ukraine ${ }^{3}$.

\footnotetext{
${ }^{2}$ Code of Ukraine on administrative offences of December 07, 1984 No. 8073-X. sheets of the Supreme Soviet of the Ukrainian SSR. 1984. Annex to No. 51. P. 1122. (with changes and additions)

${ }^{3}$ The administrative activities of the police: a Training manual. Third edition, revised / For zag. edits. Kovalenko V. / Olefir V., Konstantinov S., Bratel S., et al. Kiev: KNT, 2011. 512 p.
} 
Principles of the patrol police of Ukraine. The work of the patrol police is based on the following basic principles: the rule of law; the rule of law; respect for human rights and freedoms; openness and transparency; political neutrality; interaction with society on the principles of partnership and continuity (Section II of the Law of Ukraine "on the National police"). A brief look at their content.

AcOSACing to the principle of the rule of law, a person, his rights and freedoms are recognized as the highest values and determine the content and direction of the state.

The principle of legality is that the police act solely on the basis, within the powers and in the manner prescribed by the Constitution and laws of Ukraine. Police officers are prohibited from carrying out both criminal and illegal orders and orders. Therefore, any orders, orders and instructions of the highest bodies, heads, officials and officials, official, political, economic or other expediency are not a reason for violation by the police of the Constitution and laws of Ukraine.

During the performance of its tasks, the police adhere to and promote the implementation of the principle of respect for human rights and freedoms guaranteed by the Constitution and laws of Ukraine, as well as international treaties of Ukraine, the consent to be bound by the Verkhovna Rada of Ukraine. Restriction of human rights and freedoms is allowed only on the grounds and in the manner prescribed by the Constitution and laws of Ukraine, as necessary and to the extent necessary to perform the tasks of the police. Such restrictions must be a justifiable goal, and therefore must be immediately terminated if the purpose of the application of such measures is achieved or there is no need for their further application ${ }^{4}$.

Police officers are prohibited under any circumstances from facilitating, carrying out, inciting or tolerating any form of torture, cruel, inhuman or degrading treatment or punishment. In case of detection of such actions, each police officer is obliged to immediately take all possible measures to stop them and be sure to report to the direct management of the facts of torture and the intention of their use and notify the pre-trial investigation body authorized to investigate the relevant crimes committed by the police.

In addition, any privileges and restrictions on the grounds of race, color, political, religious and other beliefs, sex, ethnic and social origin, property status, place of residence, language or other grounds are prohibited directly in the activities of the police.

\footnotetext{
${ }^{4}$ Kolpakov V. administrative responsibility (administrative-tort law): studies. benefit. / V. Kolpakov. Kyiv: Yurinkom Inter, 2008. 256 p.
} 
The police operate on the principles of openness and transparency within the limits defined by the Constitution and laws of Ukraine. Which is embodied in the fact that:

- the police shall ensure constant informing of state authorities, local self-government bodies, the public about their activities in the field of protection and protection of human rights and freedoms, combating crime, ensuring public security and order;

- the police shall ensure access to public information of which it is the owner, in the manner and in accordance with the requirements established by law;

- the police may release restricted information only in cases and in the manner prescribed by law;

- normative legal acts regulating the activities of the police must be published on the web-portal of the Central police authority (and with limited access-published in cases and in the manner prescribed by law);

- draft normative-legal acts concerning human rights and freedoms shall be subject to public discussion in accordance with the procedure established by the Minister of internal Affairs of Ukraine.

The principle of political neutrality is that the police ensure the protection of human rights and freedoms regardless of political beliefs and party affiliation, as well as decisions, statements or positions of political parties and public associations 5 .

It is forbidden to use any objects on which the symbols of political parties are depicted and to carry out political activities, to express personal attitude to the activities of political parties during the performance of official duties, as well as to use official powers for political purposes.

The activities of the police are carried out in close cooperation and interaction with the population, territorial communities and public associations on the principles of partnership and are aimed at meeting their needs. The assessment of the level of public confidence in the police is carried out by independent sociological services in accordance with the procedure established by law, and the level of public confidence in the police is the main criterion for assessing the effectiveness of police bodies and units

Principle of continuity. The police ensure the continuous and round-theclock performance of their tasks. Everyone has the right at any time to seek the assistance of police (AOP), and the latter has no right to refuse to consider or to defer consideration of petitions for the rights and freedoms of individuals and legal entities, interests of society and state from illegal encroachments

\footnotetext{
${ }^{5}$ About Central Executive authorities: the law of Ukraine of 17 birches. 2011 No. 3166-VI. Sheets of the Supreme Soviet of the USSR. 2011. No. 38. P. 385.
} 
with reference to weekend, holiday or non-working day or after business hours ${ }^{6}$.

\section{Tasks and functions of patrol police}

The tasks of the National police (which includes the patrol police) are defined in article 2 of the Law of Ukraine "on the National police":

- ensuring public safety and order;

- protection of human rights and freedoms, as well as the interests of society and the state;

- the crime-fighting;

- provision, within the limits defined by law, of assistance services to persons who, for personal, economic, social reasons or as a result of emergency situations, need such assistance.

These are common tasks facing each structural unit of the National police of Ukraine. The special tasks of the patrol police include:

1. Ensuring public order and public safety; ensuring the safety of persons, protection of their rights, freedoms and legitimate interests; creating a state of protection of vital interests of society, concentrated in its material and spiritual values, normal conditions of human life, the activities of enterprises, institutions and organizations.

2. Prevention of criminal and administrative offences; prevention, detection and suppression of criminal and administrative offences, cases of domestic violence, as well as identification of the causes and conditions conducive to their Commission.

3. Interaction with society. Which is the "police and society", which is cooperation and interaction with the public, community organizations, other units of internal Affairs bodies, bodies of public authority, to prevent violations, ensure safety, reduce crime, and build trust between police and the community.

4. Ensuring road safety; organization of control over compliance with laws and other legal acts on road safety.

Patrol service according to the tasks assigned to it carries out:

- round-the-clock patrolling of the service area to ensure proper protection of public order and public safety;

- control over observance of traffic rules in order to ensure its safety and traffic regulation;

- rapid response to reports of offences, as well as timely response to assist citizens to reports of offences;

\footnotetext{
${ }^{6}$ The Constitution of Ukraine of 28 red. 1996 Vedomosti of the Verkhovna Rada of Ukraine. 1996. No. 30. P. 141.
} 
- emergency care;

- providing emergency assistance to victims of accidents, offenses, accidents, fires and other emergencies before the arrival of the competent services;

- self-identification of offences during patrol and in other cases provided by the legislation, draws attention to offences for the purpose of their prevention, suppression, documentation and prosecution;

- termination of criminal and administrative offences, applying for this purpose the rights and powers provided by the legislation:

- review in cases and in the manner prescribed by law, considers cases of administrative offenses and applies administrative measures to offenders;

- detention of offenders and their delivery to divisions of lawenforcement bodies.

- protection of the scene, that is, takes measures to protect and preserve the scene in its original, unchanged condition until the arrival of authorized persons, in particular investigative task forces

- cooperation with other structural units of internal Affairs bodies.

- communication and cooperation with society:

- performance of other powers provided by normative legal acts of the Ministry of internal Affairs.

- other functions aimed at achieving their objectives.

\section{Organization of work of patrol police of Ukraine}

Citizens of Ukraine at the age of 18 years who have complete General secondary education, regardless of race, color, political, religious and other beliefs, gender, ethnic and social origin, property status, place of residence are accepted for service in the police. A prerequisite is the possession of a fluent Ukrainian (state) language. The Ministry of internal Affairs of Ukraine ${ }^{7}$ approves requirements to the level of physical training.

For candidates who are accepted for service in the patrol police, in addition to General, additional requirements are put forward:

- age from 21 to 35 years;

- complete General secondary or higher education;

- availability of a driver's license category b;

- no criminal record;

- fluency in Ukrainian language;

${ }^{7}$ About the statement of Regulations on Department of the organization of activity of divisions of patrol service of special purpose of the Ministry of internal Affairs of Ukraine : The order of the Ministry of internal Affairs of Ukraine of August 11, 2014 No. 809. URL: search.ligazakon.ua/l_doc2.nsf/link1/MVS518.html. 
- physical health and moral stability.

The selection of candidates takes place in several stages: filling out the questionnaire; checking the General level of knowledge; psych diagnostic test; medical examination; checking driving skills; personal interview; theoretical training; professional training. The last two stages are regulated by the Regulation on the organization of courses of primary professional training (specialization) of employees of patrol units, which is approved by the order of the Ministry of internal Affairs of 16.03.2015 No. 276.

Theoretical education and training of patrol officers is in the form of courses on the basis of educational institutions of the interior Ministry, they are assigned to the first special rank of private police) and the probation period up to one year. Students are divided into training groups of no more than 30 people, from which the commander of the group is determined. Students during training may not be involved in the service as part of the daily orders, to maintain internal order in educational institutions, as well as to protect public order After successful completion of training, students receive a document of the established sample, which is attached to their personal files, and are sent to the place of service.

The personnel of the patrol force is equipped with acOSACing to the Provisions on service by ordinary and authoritative bodies of internal Affairs, approved by the decree of the Cabinet of Ministers of the Ukrainian SSR of July 29, 1991 No. 114, the relevant provisions regulating the activities of the divisions of patrol service of the MIA of Ukraine and other normative-legal acts ${ }^{8}$.

The organization of activities, control over the activities of the patrol service is carried out by the head of the Department of patrol service of the Ministry of internal Affairs of Ukraine (hereinafter-STS MIA). The rights and duties of the head of the STS of the Ministry of internal Affairs are determined by the relevant Regulations on the STS of the Ministry of internal Affairs.

The officer of patrol service during performance of the official duties is the representative of the state power. Patrol police work in nonstop mode (around the clock and continuously) two days in two. Two working days consist of two shifts: day - from 7.00 to 19.00 and night-from 19.00 to 7.00. Patrolling is carried out by a police crew which consists of two police officers in clearly defined areas also works and foot patrol. The police are subordinate to the platoon commanders.

\footnotetext{
${ }^{8}$ On the Disciplinary Statute of the National police of Ukraine: law of Ukraine of 15 Mar. 2018 No. 2337-VIII. Official journal of Ukraine. 2018. No. 54. P. 1882.
} 
Employees of the patrol service of the National police have a uniform, badges and distinctions. During the patrol, the police are provided with a rubber baton, a gas canister, a special pocket, a tactical flashlight, handcuffs, a pistol "Fort-17" (9 mm caliber), two magazines and other devices to perform the tasks assigned to them. The patrol police officer has an individual badge with a personal number and a video camera that captures the work of the law enforcement officer. In addition, the police have GPS equipment that captures the movement of patrols and makes it easier to manage them.

They have the right to apply physical force, including unarmed combat techniques to ensure personal safety or the safety of others, suppression of offences, detention of the perpetrator of the offence, if the use of other police measures does not ensure the execution of police powers imposed on it by law. Police officers of the patrol service are authorized to use special means to ensure public safety and order, provided they undergo appropriate special training, and to use service dogs or horses when patrolling.

At the same time, police officers, including those who serve in the patrol police, are prohibited:

- strike rubber (plastic) batons on the head, neck, clavicle, genitals, lower back (coccyx) and stomach;

- during application of the means equipped with substances of tear and irritating action to carry out sighting firing on people, scattering and shooting of grenades in crowd, their repeated application within the zone of defeat during action of these substances;

- to shoot the cartridges equipped with rubber or similar for the properties throwing projectiles of nonlethal action, with violation of certain technical characteristics of requirements concerning distance from the person and firing in separate parts of the head and a body of the person;

- to use means of a compulsory stop of transport for a compulsory stop of motorcycles, sidecars, scooters, mopeds, vehicles engaged in passenger transport, and to apply such funds on mountain roads or roads with limited visibility, level crossings, bridges, viaducts, trestles, tunnels;

- the use of a small explosive device for the opening of premises is justified if the damage caused to the rights and interests protected by law is less than the damage that has been diverted

- apply handcuffs for more than 2 hours of continuous use or without easing their pressure.

Employees of the patrol service are authorized to use firearms in cases of:

- when a person who is detained by a police Officer with a firearm in his hands tries to approach him, reducing the distance determined by him, or touch the weapon; 
- armed attack, as well as in the case of a sudden attack with the use of military equipment, vehicles or other means that threaten the life or health of people;

- if a person detained or arrested for committing a particularly serious or serious crime escapes with the use of a vehicle;

- if a person resists with an armed weapon;

- the need to stop trying to take possession of firearms.

The use of firearms without warning is allowed.

\section{Rights and duties of the inspector of patrol police of Ukraine}

Employees of patrol service of the Ministry of internal Affairs of Ukraine have the right:

- to demand from citizens of observance of public order;

- to demand from the persons violating a public order, the termination of offenses;

- to check at citizens at suspicion in Commission of offenses the documents proving their identity, and also other documents in the cases provided by the law and the way;

- to carry out personal inspection, inspection of things and documents, the vehicle and cargo in the order established by the legislation;

- to withdraw from citizens and officials of subjects and things forbidden or limited in circulation, and also documents with signs of forgery;

- to apply measures of physical influence, special means and firearms in cases and the order provided by the legislation;

- at implementation of patrol on the vehicle to include special light, sound signals, and also in exceptional cases not to observe requirements of traffic rules;

- temporarily restrict or prohibit access of persons to a certain territory or objects, if it is necessary to ensure public order and public safety, protection of life and health of people, as well as to conduct certain investigative actions in accordance with the legislation;

- to restrict or prohibit in cases of detention of criminals at accidents, other emergency circumstances threatening life and health of people, movement of vehicles and pedestrians on separate sites of streets and highways acOSACing to the legislation;

- to use technical means and technical devices for detection and fixing of offenses acOSACing to the legislation;

- to detain citizens on the grounds and in accordance with the law and to deliver them to the internal Affairs bodies in accordance with the legislation;

- delay and ensure delivery of vehicles for temporary storage in accordance with the legislation. 
Duties of employees of patrol service:

- strictly observe the provisions of the Constitution of Ukraine, laws of Ukraine and other legal acts regulating the activities of the police, and The oath of the police;

- professionally perform their duties in accordance with the requirements of legal acts, official (functional) duties, orders of management;

- respect and not violate human and civil rights and freedoms;

- to render urgent, in particular do medical and medical, help to persons who suffered as a result of offenses, accidents, and also to the persons who appeared in a helpless condition or a condition dangerous for their life or health;

- keep information with limited access, which became known to him in connection with the performance of official duties;

- to inform the direct head of the circumstances precluding his further service in the police or stay in office.

- restrict human rights and freedoms only in the manner and in cases established by law;

- referring to the person, say Hello, put his right hand to the headdress, to give his name, position, special rank and produce on request official identity, providing an opportunity to see it with the above information, while not letting him out of my hands;

- during communication with the person to observe accurately norms of office ethics;

- to warn drivers of vehicles of the danger which has arisen on the way of their movement, and to take measures for their elimination;

- during carrying out repair and construction and other types of works on streets and roads to provide optimization of traffic and to control observance of rules of traffic safety;

- if possible, to assist the driver in case of malfunction of his vehicle;

A police officer on the entire territory of Ukraine, regardless of the position he holds, location and time of day, in the event of any persons contacting him with a statement or report on events threatening personal or public safety, or in the case of direct detection of such events, is obliged to take the necessary measures to save people, provide assistance to persons who need it, and report this to the nearest police authority.

The employee of patrol service is forbidden:

- violate the rules of the road and the rules of improvement, if it is not related to the need to perform official activities;

- communicate with people while in a service vehicle;

- give directions or wishes to road users with incomprehensible gestures, use a loudspeaker or special signals for other purposes; 
- identify disrespect or ill will towards citizens;

- other that is provided by the legislation, including normative legal acts of the Ministry of internal Affairs.

In case of Commission of illegal acts, police officers bear criminal, administrative, civil and disciplinary responsibility according to the law.

\section{Basic principles of police protection}

The security police is the only security structure in Ukraine, whose employees have the rights and powers defined by Law for armed protection and the use of power functions for offenders. After the establishment of the National police, legal entities and individuals who used the services of the State security service came under the protection of the security police.

August 10, 1993 Decree of the Cabinet of Ministers of Ukraine No. 615 "About measures on improvement of protection of objects of state and other forms of ownership", on the basis of units of the security at internal Affairs bodies, the State security service under MIA of Ukraine, which acted on a self-financing basis.

The service was entrusted with the protection of particularly important state objects, the duties of the law enforcement State service and a set of paid security services that have developed in market conditions.

During 1993-1998, the State security servise (SSS) Department addressed a range of personnel, legal, technical, financial, economic and other issues, developed and implemented policy directions for the further development of the security service, it is planned to improve management and develop a regulatory framework, strengthen the economic condition, carry out technical re-equipment and ensure the reliability of protection, improve logistics and improve personnel management.

Given the complexity of the economic situation, which turned out to be security, work was done to improve the system management units, which was now aimed at improving security and strengthening the economic condition of the units. This allows the system of the State security service under MIA of Ukraine was created in service of the special police protection "Titan", a collection Service, the protection of banknotes and securities and the Commission for tender for special armored vehicles that were used for collection and transportation of values. Thus, in June 1998, 95 regular units of the collection Service were established in the SSS system, with which 13764 contracts were concluded. For five years of the existence the regular number of special forces of militia of protection "Titan" reached 3 thousand people who carried out about 9 thousand security actions on support of valuable freights, papers and money, carried out protection of property of legal entities and personal safety of physical persons, rendered complex protection of objects and so forth. Also reorganization of organizational and 
staff structure was carried out, personnel apparatuses were reformed, thanks to what the Concept of uniform system of professional training of a category of personnel of the State security service was realized.

Subsequently, the centre was established to provide informational support for subdivisions of the bonds, the system of the local computer network HUDSO and email system at the level of the "Center-region", developed the Concept of management of advertising activities and the Regulation on promotional activities of SSS Ministry of internal Affairs of Ukraine ensured the publication of materials in mass media about the activities of the departments of SSS, he began producing a variety of promotional and souvenir products.

18 December 1998 based on the existing legal framework and legislative acts of Ukraine in connection with the order SSS at the interior Ministry of Ukraine in the Department of State security service it was decided to open a Museum of the history of SSS.

Defined in 2000 by the Ministry of internal Affairs Board of Ukraine areas continues the process of restructuring the organizational structure of SSS, its financial-economic activities, the introduction of new technical means of protection, the Institute of civic guards, and the exemption of the police from performing irrelevant tasks, separation of power and self-supporting functions.

On the way of such transformations, the number of employees of the administrative and managerial apparatus was significantly reduced, unnecessary management links disappeared, and unprofitable divisions were liquidated.

It was also extremely important that considerable attention was paid to the training of personnel. Eight training programs for initial training, retraining and advanced training of security personnel have been developed and implemented. Such important tasks as special training of employees for protection of schools and preschool institutions, specialists in marketing and sales of security services on which further development of service, its competitiveness largely depended were solved.

Currently, the Department has carried out operational tests and introduced a new generation of centralized surveillance systems, such as: "Chestnut", "signal", "Ozone", "Integral", "alpha", "Danube", receiving and control devices VBD-6, Is-8001, etc. In order to ensure the protection of telephoned objects, radio monitoring was introduced.

Within the limits of the powers, the State security service carried out licensing of services in protection by non-state security formations. To ensure the high quality of security services and social protection of employees in the State security service created Ukrainian security and insurance company "USC". 
In June 2007, the State security service consisted of 192 combat units, 146 collection services, 38 Special Forces units "Titan" and other services, which employed more than 48 thousand employees. It is possible to note also considerable material and technical potential of service: 251 points of the centralized supervision, modern means of communication, Park of special cars, the newest firearms. Specialized educational institutions, one secondary and two higher vocational schools have been established to train employees in the SSS. Under protection of Service there were more than 177 thousand objects among which 86800 housing of citizens. At the same time, 486 detention groups took over the service, which prevented about 37 thousand crimes and detained more than 40 thousand criminals. Elite divisions of SSS "Titan", in turn, provided support of freights and values, safety of the Ukrainian and foreign citizens (290 physical persons).

November 7, 2015 according to the Law of Ukraine "On the National police" and the decree of the Cabinet of Ministers of Ukraine from 13 October 2015 No. 834 "Questions of functioning of police protection as territorial bodies of the National police and the elimination of some territorial bodies of the Ministry of internal Affairs", was created by a police Department protection, as well as control and police protection as the regional offices of the National police. The security police has more than 200 centralized security consoles, modern communications equipment, a fleet of special vehicles, the latest firearms.

All protected objects with the help of technical means are connected to centralized security panels. Units of the security police are equipped with alarm buttons and relevant information labels 3085 emergency call places. For the organization of remote control of the operational situation in places of mass stay of citizens, 604 video surveillance systems are installed. Detention groups-mobile squads round the clock patrol the cities and regions of Ukraine. At the same time, about 500 detention groups take over the service.

In 2009 under protection there were almost 95 thousand objects and over 92,5 thousand dwellings of citizens (apartments, offices, shops, shopping centers, strategic objects, country houses and so forth). The guard police are part of the National police. The Cabinet of Ministers of Ukraine by its resolution No. 834 of 13 October 2015 established as territorial bodies of the National police the Department of police protection as an interregional territorial body of the national Police; The police Department of protection of objects of strategic importance, as well as police protection in areas of Kiev, the Autonomous Republic of Crimea and Sevastopol, Kryvyi Rih city Department police protection in the Dnipropetrovsk region, the Mariupol Interdistrict Department of management of police protection in the Donetsk region, as well as police protection to physical security in Kiev. To protect 
individuals, goods and valuables, property of individuals and legal entities in the structure of the security Police there are physical security units ${ }^{9}$.

\section{Special police}

OSAC (ADB. from the Operational-Sudden Action Corps) - a unit of the National police to deal with emergencies, the level of which is so high and complex that it may exceed the capabilities of the rapid response forces or operational search units.

On March 12, 2015, interior Minister Arsen Avakov in his report "100 days of Government activity: the way to stabilization" said that on the basis of special purpose battalions and special forces of the interior Ministry will be created a single special purpose unit and it will be called OSAC (Corps of operational and sudden action).

On March 4, 2016, the first 37 fighters of group "A" of Special Forces OSAC, after a rigorous selection and two-month training course, began to perform their duties. The head of the National police Hatia Dekanoidze noted that today is another historic day in the history of the National police of Ukraine. With the support of American partners, the first commandos who were selected among 900 candidates received certificates of completion of the training course. During the two-month training course, they adopted the experience and tactics of police special operations of the drug enforcement administration (DEA) of the U.S. Department of justice and the bortac border patrol. Eighty percent of the course was practical. The practical part includes classes on fire training, which is the basic discipline, as well as tactics in extreme conditions, in particular, indoors and in the forest. In addition, the candidates received skills of sniping, knife fighting, and tactics of action in the detention of criminals using cars. The theory included the study of the legal basis of the police special forces, familiarization with the qualification of crimes, the passage of psychological training.

On March 17, 2016, as part of the creation of the witness protection program, the first trainings with US Marshal were launched as part of the OSAC of the national Police. In addition, in two weeks 17 instructors of group "U" of Special Forces "OSAC" of National police of Ukraine received certificates of completion of training. Also on this day, 1 April, began the selection of candidates for the unit "OSAC" throughout Ukraine. The special unit is planned to recruit 3076 police officers.

\footnotetext{
${ }^{9}$ The administrative activities of the police in questions and answers: textbook / for zag. ed. Sciences, prof., Acad. National Academy Of Legal Sciences Of Ukraine O. Bandurka. Ministry of internal Affairs of Ukraine, Kharkiv. NATs. UN-t EXT. cases'. Kharkiv: HNUVD, 2017. 242 p.
} 
On July 22, 2016, a representative of the FBI handed Ukrainian soldiers certificates of completion of the basic course with the use of special weapons and tactics. For 10 days instructors of the Federal Bureau of investigation of the USA shared experience of detention of violators of a law and order with fighters of police Special Forces OSAC.

In General, in 2016, the special unit OSAC began its work in Kiev, Kiev, Sumy, Kharkiv, Donetsk and Rivne regions. A special role was assigned to the units in the last two areas, for the specifics of work in the frontline settlements of the Donetsk region and the fight against the amber mafia in the Rivne region.

On January 31, 2017, soldiers of the Special Forces OSAC together with the police regiment "Kiev" and the special purpose battalion of the criminal and preventive units of the GUNP in the Donetsk region were sent to the frontline city of Avdiivka, which was attacked by militants and gangs the day before. All fighters have experience in combat and proper training. Among the tasks of law enforcement officers to preserve law, order, and prevent looting. For service in the line of fire, the police are provided with special vehicles.

On May 28, 2017, a special unit OSAC was sent to Krasnogorovka, Donetsk region, shelled by terrorists, to assist citizens, as well as to strengthen the protection of public order and destroyed administrative buildings. The regional police Department reported that the commandos will serve to protect public order, evacuate people on armored vehicles if necessary, to carry out anti-terrorist activities ${ }^{10}$.

On June 22, 2018, the 14th edition of the soldiers of the special purpose police units OSAC in Cherkasy and Ternopil regions took place. This issue completely completed the formation of the territorial divisions of OSAC in Ukraine.

Tasks OSAC:

- develops, prepares and conducts special operations to capture dangerous criminals;

- stops offences committed by members of criminal groups;

- release the hostages;

- provides power support during operational search activities, investigative (search) and secret investigative (search) actions, as well as measures to ensure criminal proceedings;

- providing support to other police units with the goal of providing superior firepower of the offenders;

\footnotetext{
${ }^{10}$ Provision by the internal Affairs bodies of international legal standards of human rights in the protection of public order. Scientific-practical, documentary-source and educationalmethodical complex (in 3 parts). Kyiv: Institute of state and law. V. Koretsky NAS of Ukraine, 2010. $460 \mathrm{p}$.
} 
- participates in anti-terrorist operations conducted by the anti-Terrorist center under the security Service of Ukraine;

- studies, summarizes domestic and foreign experience, as well as the methodology of similar foreign units in this area of work;

- ensures the implementation of security measures for persons involved in criminal proceedings.

The greatest need to attract OSAC has a criminal unit MDNP in the Donetsk region, in a region where since 2014 there is a war, where there is a large number of weapons, ammunition, and where people who commit crimes can be armed. In the absence of Special Forces to perform special operations to detain criminals participated special battalion MDNP in the Donetsk region.

In the structure of the regional Central Board of the Donetsk region formed units OSAC, which has more than 100 people, has a duty unit, headquarters, staff instructors, inspection Department, analysts who develop special operations, and directly-a special forces team of 70 people.

On October 28, 2016, the first 17 members of the police special forces completed the training course and received OSAC certificates. This is the assault squad, whose task in combat is neutralization prospecting groups of the opponent, the detention of terrorists, the release of the hostages. Most of them - fighters of the former "Falcon", have experience of service in the conditions of anti-terrorist operation and took direct part in special operations on the demarcation line.

In addition, OSAC units take part in all-Ukrainian anti-terrorist exercises together with the SBU, NSU and GNSU units. So in 2016, joint exercises were held to liberate the Embassy of the state of Israel in Kiev, the international airport "Boryspil", Kharkiv regional state administration and other important objects of national and international importance.

On November 21, 2017, joint exercises of Special Forces of the National Guard of Ukraine - "omega", The state border service - "Dozor" and the National police of Ukraine "OSAC" were held at the training ground of the National guard of Ukraine in Novy Petrovtsi, Kyiv region, with the technical assistance of the US Government. The commandos worked out the elements of a parachute landing from a helicopter with the use of various equipment, and established the evacuation of the group from a given area with the help of a special rope.

According to the state special unit, "OSAC" consists of Department and managements "OSAC" MDNP in and Kiev, in total-1206 police officers.

Special operations units are staffed on a voluntary and contractual basis.:

1. They have experience of practical work (service) in the internal Affairs bodies, the National police, the Armed forces, the security Service of Ukraine for at least three years. 
2. Took part in carrying out anti-terrorist operation as a part of the divisions formed according to the legislation of Ukraine.

3. Were interviewed by the leadership of the Department of OSAC.

4. They underwent special psychological and medical examinations, acOSACing to the results of which they were recognized as fit for service in special operations units.

5. Successfully passed the standards for physical training and passed a five-day endurance course.

6. Passed specialized training in The Department of organization of the Corps of operational and sudden action and successfully passed the exams.

The candidate (with his consent) to fill the vacancy in the Department of special operations of the special unit OSAC can be surveyed by specialist services using computer polygraph.

The "OSAC" team gear is designed for a variety of special situations, including close combat in an urban environment. Commandos are provided with summer (camouflage MULTICAM) and winter (camouflage NATO a-ODU AU) uniforms and shoes of the established sample, as well as personal protective equipment (gas masks, helmets, body armor, shockproof and bulletproof shields, protection for hands and feet).

OSAC units use pistols, submachine guns, carbines, shotguns and sniper rifles. Tactical AIDS such as police dogs stun grenades and tear gas grenades.

As of the beginning of 2016, special forces soldiers OSAC received pistols Glock 17 and Jericho 941, shotguns "Fort-500", machine guns "Fort-221", "Fort-224", carbines "Z-10", "Z-15", machine guns "Fort-401", hand grenade launchers "Fort-600", sniper rifles "Fort-301" and Barrett M107A1.

For rapid hacking doors (castles, hinges or destruction the entire door frame) can use battering rams, shotguns with destructive charges, explosive packages.

While ensuring public safety at mass events, OSAC teams also use nonlethal weapons: pepper spray canisters, shotguns with rubber charges, weapons firing pepper balls, tear gas grenades, and stun grenades.

Fighters of group "A" (assault groups) for work on a line of fire are provided with special transport: armored cars "VARTA" which were developed specially for special purpose police and the modernized BRDM-2 which are used only in special operations in a zone of military operations in the East of Ukraine.

Suspects also use modified buses, vans, trucks and other vehicles that look like regular vehicles to avoid detection during operations. In particular, it is armored Toyota Land Cruiser, Volkswagen T6, and Peugeot Boxer. 
In addition, the police actively use helicopters for aerial reconnaissance, transportation of personnel, wounded or detained. For this purpose at the disposal of Special Forces, there are mi-8MSB-B helicopters.

\section{CONCLUSIONS}

The creation of the patrol police is the first example in Ukraine, when changes in legislation were combined with an attempt to create a new institution and innovations such as transparent selection of employees, their training in new procedures, standards and skills, as well as appropriate financial support. This is a large-scale step towards reforming the internal Affairs bodies, which consists of completely new employees seeking qualitative changes.

More modern technical devices, which are used by employees of patrol service, allow them to react quickly to offenses, and also to warn and reveal them.

Companies and battalions of special purpose are created mainly for the protection of public security and order. Laws and other legal acts regulate the list of special purpose police units and its functions. A separate stage of the reform of the internal Affairs bodies is the creation of the corps of operational and investigative actions. A high level of physical training and possession of special skills that allow them to perform the tasks assigned to them characterize special police officers.

Thus, the State security service and special purpose police units perform extremely important functions, including ensuring public order and public security. Relations of divisions of the State security service with legal entities and citizens in connection with provision of services in protection and safety, responsibility, the rights and duties of the parties are defined by contracts, and services which it provides-paid.

\section{SUMMARY}

The article reveals the legal regulation and principles of the patrol police of Ukraine, the principles of the patrol police of Ukraine, the tasks and functions of the patrol police, the organization of the patrol police of Ukraine, the rights and duties of the inspector of the patrol police of Ukraine, the basic principles of the security police, the special purpose police

\section{REFERENCES}

1. Administrative activities of the police of Ukraine: textbook / ed. Sciences, Assoc. V. Sokurenko; Ministry of internal Affairs of Ukraine, Kharkiv. NATs. UN-t EXT. cases'. Kharkov: HNUVD, 2017. 432 p.

2. The administrative activities of the police in questions and answers: textbook / for zag. ed. Sciences, prof., Acad. National Academy of Legal 
Sciences Of Ukraine O. Bandurka. Ministry of internal Affairs of Ukraine, Kharkiv. NATs. UN-t EXT. cases'. Kharkiv: HNUVD, 2017. 242 p.

3. Administrative activities: studies. benefit. for students. in Moscow. Studies'. zacl. / Ed. collective: M. Kovaliv, Z. Kisil, D. Kalayanov, etc. Kyiv: legal unity, 2009. $432 \mathrm{p}$.

4. Administrative (police) activities of the police: General part: Textbook. Second edition / ed. V. Kovalenko, Y. Rymarenko, V. Olefir Kyiv: "Direct Line", 2012. $816 \mathrm{p}$.

5. The administrative activities of the police: a Training manual. Third edition, revised / For zag. edits. Kovalenko V. / Olefir V., Konstantinov S., Bratel S., et al. Kiev: KNT, 2011.512 p.

6. Violence in the family and the police to overcome it: training manual for cadets of higher educational institutions of the Ministry of internal Affairs of Ukraine / compilers: Zaporozhtsev A., Laban A., Zabroda D., Bassist I., Drozdova I., Brizhik V. Kiev, 2012. 246 p.

7. The administrative activities of the police in questions and answers. Textbook. Kyiv: PE "Direct Line", 2012. 224 p.

8. Kurennoy E. Legal and organizational bases of activity of patrol service of the Ministry of internal Affairs of Ukraine: Uch. - method. possib. I E. Kurennoy, D. Zabroda, Dnepropetrovsk: Dnepropetr. state University EXT. del, 2009. 104 p.

9. Provision by the internal Affairs bodies of international legal standards of human rights in the protection of public order. Scientific-practical, documentary-source and educational-methodical complex (in 3 parts). Kyiv: Institute of state and law. V. Koretsky NAS of Ukraine, 2010. 460 p.

10. Mechanisms of interaction between state authorities and nongovernmental organizations in combating child abuse. Educational and methodical manual (ed. Shevchenko K., Trubavina I. Kiev: legal Counsel. 2005. $452 \mathrm{p}$.

11. Kolpakov V. administrative responsibility (administrative-tort law): studies. benefit. / V. Kolpakov. Kyiv: Yurinkom Inter, 2008. 256 p.

12. Mironyuk, G. bodies of internal Affairs as subjects of the enforcement proceedings on cases of administrative offences: proc. benefit. / R. Mironyuk, S. Goncharuk. - Dnepropetrovsk: Dnepropetr. state University EXT. del, 2006. 96 p.

13. Administrative responsibility in Ukraine: studies. no. / V. Gumenyuk, G. Yagupov, O. Salmanova, etc.; for the General editorship of A. Kasuka. Kharkiv: HNUVD, 2007. 80 p.

14. The Constitution of Ukraine of 28 red. 1996 Vedomosti of the Verkhovna Rada of Ukraine. 1996. No. 30. P. 141. 
15. About Central Executive authorities: the law of Ukraine of 17 birches. 2011 No. 3166-VI. Sheets of the Supreme Soviet of the USSR. 2011. No. 38. P. 385 .

16. On the National police: law of Ukraine of 02 July 2015 URL: http://www.zakon1.rada.gov.ua.

17. On the prevention of domestic violence: the law of Ukraine of January 15. 2001 Vedomosti of the Verkhovna Rada of Ukraine. 2002. No. 10. P. 70.

18. On prevention of corruption: law of Ukraine No. 1700-VII of 14 October 2014. Voice of Ukraine from 25.10.2014 № 206.

19. On the purification of power: law of Ukraine of September 16, 2014 No. 1682-VIII. Information of The Verkhovna Rada. 2014. No. 44. P. 2041.

20. On the Disciplinary Statute of the National police of Ukraine: law of Ukraine of 15 Mar. 2018 No. 2337-VIII. Official journal of Ukraine. 2018. No. 54. P. 1882.

21. About the state secret: the law of Ukraine of January 21, 1994. No. 3855-XII. Sheets of The Verkhovna Rada of Ukraine. 1994. No. 16. P. 93 (as amended).

22. About addresses of citizens: the law of Ukraine of 02 Oct. 1996 No. 393/96. Sheets of The Verkhovna Rada of Ukraine. 1996. No. 47. P. 256 (as amended).

23. About public associations: the law of Ukraine of March 22. 2012, No. 4572-VI. Sheets of The Verkhovna Rada of Ukraine. 2013. No. 1. C. 1.

24. About information: law of Ukraine of 02 Oct. 1992 No. 2657-XII. Sheets of The Verkhovna Rada of Ukraine. 1992. No. 48. P. 650 (as amended).

25. About access to public information: the law of Ukraine of January 13, 2011 No. 2939-VI. Sheets of The Verkhovna Rada of Ukraine. 2011. No. 32. P. 314

26. On local state administrations: Law of Ukraine No. 586-XIV of 09 April 1999. Sheets of The Verkhovna Rada of Ukraine. 1999. No. 20-21. P. 190.

27. About judicial system and the status of judges: the Law of Ukraine: from June 2. 2016 No. 1402-VIII. Official journal of Ukraine. 2016. No. 56.

28. On the participation of citizens in the protection of public order and the state border: the law of Ukraine of 22 June. 2000 No. 1835-III. Official journal of Ukraine. 2000. No. 30. P. 1248.

29. On international treaties of Ukraine: law of Ukraine of June 29. 2004 No. 1906-IV. Sheets of The Verkhovna Rada of Ukraine. 2004. No. 50. P. 540.

30. Code of Ukraine on administrative offences of December 07, 1984 No. 8073-X. sheets of the Supreme Soviet of the Ukrainian SSR. 1984. Annex to No. 51. P. 1122. (with changes and additions) 
31. About the statement of Regulations on the Ministry of internal Affairs of Ukraine: the resolution of the Cabinet of Ministers of Ukraine of August 13, 2014 No. 401. Uryadovy courier from 10.09.2014. No. 165.

32. About formation of some territorial bodies of the Ministry of internal Affairs: The Resolution of the Cabinet of Ministers of Ukraine of May 20, 2015 No. 314. URL: http://ligazakon.ua/1_doc2.nsf/link1/KP150314.html

33. About the statement of the Order of consideration of addresses and messages concerning abuse of children or threat of its Commission: the Order of Ministry of social Policy of Ukraine, the Ministry of internal Affairs of Ukraine, MES of Ukraine of August 19, 2014 No. 564/836/945/577. Official Bulletin of Ukraine from 03.10.2014. 2014. No. 77. P. 409, p. 2214.

34. Instruction on the organization of activities of duty units of bodies and divisions of internal Affairs of Ukraine aimed at protecting the interests of society and the state from illegal encroachments: order of the Ministry of internal Affairs of Ukraine of 28 APR.2009 No. 181. URL: http://www.zakon1.rada.gov.ua.

35. About the statement of Regulations on Department of the organization of activity of divisions of patrol service of special purpose of the Ministry of internal Affairs of Ukraine: The order of the Ministry of internal Affairs of Ukraine of August 11, 2014 No. 809. URL: search.ligazakon.ua/ 1_doc2.nsf/link1/MVS518.html.

36. About the statement of Regulations about the patrol service of the interior Ministry: the order of MIA of Ukraine from July 02, 2015 No. 796 (is Registered in Ministry of justice of Ukraine 03.07. 2015 No. 777/27222). URL: www.zakon1.rada.gov.ua.

37. On approving the Instructions on registration of employees of patrol service of the interior Ministry materials on administrative violations in the sphere of ensuring road safety: the order of the MIA of Ukraine of July 10, 2015 No. 842. URL: //search.ligazakon.ua/l_doc2.nsf/link1/RE27275.html

38. About the statement of rules of conduct and professional ethics of persons of ordinary and commanding structure of police of Ukraine: The order of the Ministry of internal Affairs of Ukraine of February 22. 2012 No. 155. Official Bulletin of Ukraine from 21.05.2012. No. 36. P. 342.

39. About questions of application of the administrative legislation of Ukraine by bodies of internal Affairs of Ukraine: the order of the Ministry of internal Affairs of Ukraine of October 04, 2013 No. 950. URL: www.zakon1.rada.gov.ua.

40. About the statement of the Instruction on accounting of administrative offenses: the order of the Ministry of internal Affairs of Ukraine of November 07, 2012 No. 1017. URL: www.zakon1.rada.gov.ua. 
41. Approval On approval of the Instruction on organization of activity of district police officers [Electronic resource]: the order of MIA of Ukraine from 28.07.2017, No. 650 (Registered in Ministry of justice of Ukraine 21.08.2017, No. 1041/30909). URL zakon3.rada.gov.ua/laws/show/z1041-17.

42. About the organization of response to messages on criminal offenses, other offenses, emergency situations and other events and providing operative informing in bodies and divisions of internal Affairs of Ukraine: The order of the Ministry of internal Affairs of Ukraine of October 22. 2012 No. 940. Official journal of Ukraine. 2012-No. 9. C. 105. C. 350.

\section{Information about the author: Rachinska I. M.,}

Candidate of Law, Associate Professor, Associate Professor at the Department of Administrative,

Criminal Law and Procedure, International University of Business and Law 37-A, 49 HGD str., Kherson, 73040, Ukraine 